\title{
Creative and Sustainable Tourism: The Case of Ainu in Japan*
}

\author{
Edgar Bellow**, Thomas Majd ${ }^{* * *}$, Cecilia Casalegno ${ }^{* * * *}$
}

\begin{abstract}
Tourism is one of the world's fastest growing business sectors and a key economic contributor around the world. In Japan, Hokkaido is a popular tourist destination for both domestic and international tourists because it provides a unique natural landscape, climate, and culture due to its geographic location and the presence of the Ainu. The Ainu population are an indigenous people of Japan and Russia. Despite the Ainu are one of the oldest examples and signs of tradition and heritage, one of the biggest challenges for them to play a key role in tourism is relating to the relationship's imbalances with other members of the community. To this end, the aim of the paper is to explore the nature of relationships in the region, under the lens of stakeholder theory.

We illustrate some possible avenues to restore the Ainu as protagonists of value creation processes in their own community, which might increase the benefit for tourists, sustainable performances of the area and the happiness and wellbeing of such vulnerable community.
\end{abstract}

Keywords: Ainu-Japan; Joint Interests; Local Value Creation; Creative Tourism; Multi Stakeholders Initiatives; Power Imbalance.

\section{When Powerless Stakeholders Are Critical: An Introduction}

It is widely assumed (Siddle, 2003), not only outside but also inside Japan, that the country is mono-ethnic. However, based mainly on the island of Hokkaido in the north of the country, close to Russia, live the Ainu people, who are both ethnically and culturally different from the majority of the Japanese. The latest census of the Ainu conducted in 2006 counted 23,782 individuals in Hokkaido, or 0.025 per cent of the overall population. Ainu individuals outside this region are not registered, and therefore the percentage of the Ainu in the population nationwide is not known (Statistics Bureau of Japan, 2011). Although their numbers are dwindling, it is also known that many Ainu conceal their ethnic identity and try to pass for Japanese so that they can avoid discrimination (Hokkaido Ainu Policy Promotion Office, 2017). The difficulty for the Ainu is not only racism and discrimination but also the prevalent ignorance of multi-ethnic ideologies in Japan (Hohmann, 2008; Ono \&

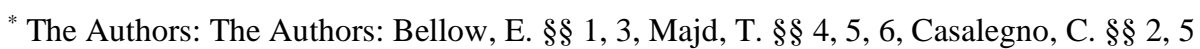

** Associate Professor of Management, NEOMA Business School, Reims, France (edgar.bellow@neoma-bs.fr)

**** Associate Professor of Management, YSchools-SCBS South Champagne Business School, Troyes Cedex, France (thomas.majd@yschools.fr)

***** Researcher and Lecturer of Management, University of Turin, Italy (cecilia.casalegno@ unito.it)
}

Bellow, E., Majd, T., \& Casalegno, C. (2019). Creative and Sustainable Tourism: The Case of Ainu in Japan. Symphonya. Emerging Issues in Management (symphonya.unicusano.it), 2, 119-132. 
Ono, 2015). At present, the culture and social values of the Ainu are consumed by the Japanese primarily through tourism (Hohmann, 2008).

The Ainu case is very interesting from many perspectives. Above all, it is representative of how a wrong people and resource management can affect a certain territory in the long term. In particular, there are significant barriers to true communication and alignment between the values of this indigenous group and the Japanese majority despite the fact that in 1997, with the enactment of the Ainu Culture Promotion Law, the Japanese government took a significant step towards the official acknowledgement of the existence of the Ainu as an ethnic minority (Hiwasaki, 2000). In examining their experiences, their power relative to members of the Japanese monoculture and the way in which this has shaped these individuals' identity over the course of history, the literature suggests that:

$\square$ The indigenous people in this country "have been deprived of
vast landholdings and access to life-sustaining resources, and they
have suffered historical forces that have actively suppressed their
political and cultural institutions" (Anaya, 2006, p. 4).

This shows that the colonial interests of members of the Japanese monoculture defined trade, land use and a power dynamic that privileged themselves, working against the development of the territory and its stakeholders (Salvioni \& Bosetti, 2014; Brondoni, 2014; Dawkins et al., 2015; Bridoux \& Stoelhorst, 2016; Fassin et al., 2017; Civera et al., 2019), without considering the beneficial role of the multi stakeholder initiatives (Brondoni et al., 2019). This paper has its roots in some issues concerning the reason that the Ainu people have been deprived of their rights to their own culture and control over their resources. First, and perhaps earliest in the process, members of the Japanese monoculture took a significant interest in perpetuating their own power structure through acts of colonialism; second, they delineated reeducation programs specifically for this community; and, third, they suppressed the political and economic rights of the Ainu to promote their own interests. To this end, cultural consumption in the form of tourism objectifies and belittles the value of the Ainu. This is in stark opposition to what the literature says about the current primary source of value creation, which has shifted from "physical resources" to knowledge and culture development (Powell \& Snellman, 2004; Bridoux \& Stoelhorst, 2016). We argue that what is said may have a positive impact on some people value creation in the short term, but such behaviour works against a long-lasting territorial value creation, which must be common (Fassin et al., 2017) and developed in the interests of all the territorial stakeholders (Salvioni \& Astori, 2013; Bridoux \& Stoelhorst, 2016). It is to underline that:

The trade-offs between and within the socio-cultural and political and economic aspects of Ainu tourism in terms of costs and benefits are likely to compromise all those results seen as "sustainable" - in terms of profit, as well as environmental and social aspects - such as the common effort to lever on local communities and their involvement process (Greenwood \& Van Buren III, 2010) and the establishment of strong relationships which can substitute transactions (Sautter \& Leisen, 1999; 
Freeman, 2010; Freeman et al., 2018), leveraging on stakeholders' trust (Greenwood \& Van Buren III, 2010) and engagement (Greenwood, 2007), as well as the power of the local heritage (Danesi, 2017).

All these aspects have already been at the same time considered through the lens of both the so-called ecotourism (Honey \& Thullen, 2003; Zeppel, 2006), related to the sustainable development issue, and creative tourism (Richards, 2009), which is aimed at replacing the old tourism models with ones that are based on local people's involvement and commitment (Codignola, 2016).

The issue on which the present paper focuses is basically relational, since apparently the Ainu's biggest problems are linked to their relationship with the other Japanese. This is interesting, since this community management, operated first of all by the government, has had an impact on the Hokkaido tourism results in recent times. Therefore, by adopting a qualitative analysis based on an integrative literature review (Snyder, 2019) and attempting to apply it to the Ainu case, with the support of a secondary data analysis, this paper discusses how it is possible to cope with power imbalances (as considered by Sautter \& Leisen, 1999; Freeman et al., 2010) in a touristic destination whose heritage is one of the most powerful factors, based on local culture development (Danesi, 2007). Finally, in order to understand how community inclusion could represent a value creation lever, the last part of the paper is dedicated to illustrating several strategies for including the Ainu population in local value creation dynamics, through the lens of the so-called "relationships/transactions strategy continuum" (Sauter \& Leisen, 1999), already considered in Freeman (1984) and Freeman et al.'s (2010) stakeholder theory.

\section{Theoretical Foundation of the Importance of (Real) Local Stakeholder Inclusion in Touristic Services}

Even though this paper explores the case of the Ainu from a socioeconomic perspective, it considers the concept of local territory value creation basically in terms of indigenous happiness and well-being (Harrison \& Wicks, 2013) outputs and elements which are currently seen as its fundamentals, such as the local communities' involvement and development (Civera et al., 2019) and the shift from transactions to relationships (Freeman et al., 2010; Fassin et al., 2017; Freeman et al., 2018) in order to create a new equilibrium (Venkataraman, 2002) based on stakeholder networks (Boiral \& Heras-Saizarbitoria 2017), mutual trust (Greenwood \& Van Buren III, 2010), engagement (Greenwood, 2007) and stakeholders initiatives (Brondoni et al., 2019). Through the lens of what is said, the local territory and culture management must be rethought from Durkheim's (1893) sociological point of view, according to which, the replication of social power structures is supported by ethnic ties.

$\square$ It is recognized that the identity of a certain stakeholder group can be negatively affected as its economic, political and cultural institutions are taken away from it, its land is traded away by unethical tactics and its philosophical point of view is seen as inferior to other cultures (McNamara et al., 2013; Boiral \& Heras- 
Saizarbitoria, 2017). Over time, literature has demonstrated that this is linked to the power imbalance (Sautter \& Leisen, 1999; Greenwood, 2007) undermining the valuable concepts of joint interests (Bridoux \& Stoelhorst, 2016) and the shift from transactions to relationships (Sauter \& Leisen, 1999; Freeman et al., 2010; Fassin et al., 2017; Freeman et al., 2018).

The above-mentioned situations are also influenced by the global change of media attitudes and the technological interdependence between national institutions and economies, which also results in increasing the power of specific entities and people to control the way in which cultural norms are created and spread on a global scale. Through social institutions and new media-based social networks, those in a position of power, namely those within hierarchical social networks, can utilize them to gain advantages with respect to cultural expectations (Morley, 2006).

Nevertheless, human beings are able to reach a new level of understanding by learning the shared language and symbols of their social environment, which ultimately exerts an effect on the culture of every level of the social world. Within this broader social context, society is, in essence, an interwoven collection of selves, which leads to the search of relationships (Freeman et al., 2010) and networks (Boiral \& Heras-Saizarbitoria, 2017) in favour of joint interests (Bridoux \& Stoelhorst, 2016) and a new stakeholder equilibrium (Venkataraman, 2002). Because these interactions are continuously changing, people may be constantly redefining themselves through give-and-take relationships and the exchange of signs, avoiding issues like racism, especially those connected to the life experiences of indigenous peoples such as those that this paper attempts to analyse, which can be seen as something grounded in the new social construction of fear as a tactic employed by both the media and the political sphere (Ono \& Ono, 2015) to destroy the common value creation for the benefit of the few.

The issue concerning the inclusion of local ties gains a strong value when a certain territory also depends on tourism. Indeed, tourism represents a good means of livelihood for local (indigenous) communities, especially when they are powerless and marginalised, since it may eventually lead to economic change and major social inclusion (Potts, 2003; Phillip et al., 2010; Jamali \& Neville, 2011; Candelo et al., 2018; Civera et al., 2019).

$\square$ Indigenous tourism is defined as tourism where the cultural exoticism of the hosting indigenous people and its products are the main attraction (Hiwasaki 2000). The above-mentioned social inclusion acts to minimise the major risk of this kind of tourism: the commodification of local heritage, culture and people for tourist consumption without the involvement of local communities in the value creation process (Greenwood, 1989).

\section{The Research Context: The History of the Ainu Within Japan's Social Shift}

The Ainu have a culture which is distinguished from that of the Japanese in terms of their food, dwelling, clothes, dance, music, religion, way of life, and language 
(Hiwasaki, 2000; Cheung, 2003). Most of them live in Hokkaido, the northern island of Japan, where they originated. The population has been declining in Hokkaido, along with the thousand or more estimated to live in the Kanto area (Cheung, 2003) but since the nationwide census does not measure ethnicity (Static Bureau of Japan, 2010), there is no data to confirm estimates outside of Hokkaido, which confirms the widespread myth of Japan as monoethnic. Nonetheless it is generally believed that actual number is much higher because many Ainu do not want to be identified as such due to persistent discrimination, and because the survey was only regionally conducted. The Ainu population in Japan is significantly small on a per capita basis compared to other countries with indigenous populations (Ramos, 1998). The method of identification is primarily the Ainu bloodline, including marriage and adoption, but ultimately Ainu self-identify, which means that their identity can be concealed (Hokkaido, 2006).

Discrimination perpetuated by the Japanese concerning the Ainu has been recorded since the Tokugawa period (1603-1868) and colonization of their culture accelerated after the Meiji Restoration in 1868 (Nakamura, 2007). Structured oppression officially started in 1899 with enactment of the Protection of the Former Primitive Inhabitants in Hokkaido (Hiwasaki, 2000; Cheung, 2003). The name of this law is very misleading; its implementation resulted in nothing but a) forced assimilation into mainstream Japanese society; b) a ban on the Ainu language, rituals and practices; c) a push for the Ainu to register with a new Japanese name, d) a requirement to cultivate the land (the traditional subsistence of the Ainu was by hunting, fishing and gathering), and, e) a requirement to relocate to approved areas (Hiwasaki, 2000; Cheung, 2003; Hohmann, 2008). This officially deprived the indigenous or tribal status from the Ainu and "Japan magically became ethnically homogeneous" (Hohmann, 2008, p. 6). Under this rule, the Ainu were isolated and alienated from Japanese society (henceforth referred to as the Japanese monoculture), and were not permitted to have political representation (Saito, 2015).

In order to maintain their power structures, therefore, it can be said that Japan is willing to overlook regional identities so that they might retain control, especially in the wake of defeat after the Second World War (Roadnight, 2002). The reason that this was the case is likely due to Japan's policy of assimilation (Ching, 2001). There was a need for the Japanese to not only impose their economic, social and political will on a colonized state or region, but also their ideals for a way of life in which the colonized would be absorbed into Japanese culture. There was a process by which Japan constructed an idea of what was Japanese, in which the colonized were seen as possessions of the state and upon which an identity was conferred, but were not awarded any of the protections of the state or the privilege of defining their own identity (Ching, 2001). The identity of these individuals was therefore that of becoming an imperial subject rather than someone who was inherently Japanese. From Korea to Taiwan to China to Okinawa, therefore, individuals were expected to conform to this identity. To this end, it can be said that the average understanding of what it meant to be Japanese in the post-war period did not distinguish between the idea of citizenship, in its guise as a legal term, and the idea of an ethnic identity and a culture of belonging to a population.

This process partially explains the willful ignorance about the Ainu by the Japanese population and such perceptions continue to play a strong role in recreating the myth of Japan as monoethnic: "most Japanese.......consider Japan a mono-ethnic country 
and take pride in that belief" (Mizuno, 1987, p. 143). This policy of assimilation was enacted for 98 years until the Ainu Culture Promotion Law was created in 1997. This new law was a significant milestone for the Ainu; first, Japan officially recognized the Ainu as an ethnic minority group, and, second, the government understood the importance of preserving the Ainu culture. But it was only in 2008 that a resolution to recognize the Ainu was approved by the Japanese government through the pressure from the international indigenous movement as UN Declaration on the Rights of Indigenous Peoples was adopted in 2007 (UN, 2007); over 25 years have passed since the Ainu were recognized by World Council of Indigenous Peoples in the first phase of its development.

The result of all of these challenges is that in today's political context, "Ainu subjectivity has become increasingly politicized as the state and other stakeholders seek to define Ainu ethnicity for future legislation" (Llewellyn, 2016, p. 50). Furthermore, present-day cultural views of the Ainu situate them as primitive (Saito, 2015); like other indigenous groups they are widely viewed as taking advantage of more prosperous echelons of society in terms of welfare and indigenous benefits now provided to them by the state, even though they have been structurally isolated from power and opportunities (Saito, 2015). This means that, from a tourism point of view, the Ainu are overwhelmingly seen as objects beneath and beyond the average Japanese individual and community. In the light of the above, the present paper research question is: in which conditions the tourism development is helpful for the Ainu community and for the territory itself?

\section{Ainu Community and (Creative and Eco) Tourism Findings Analysis: Current Facts and Open Issues}

Despite the above-mentioned situation, recent years have seen emerging and interesting phenomena in Ainu tourism (Llewellyn, 2016). The selection of Shiretoko as a UNESCO World Natural Heritage site by the International Union for Conservation of Nature (ICUN) in 2005 was supportive of the Ainu and their awareness. The ICUN mandated the inclusion of the Ainu as co-stewards as one of their major conditions of this award, acknowledging their skills and knowledge to the natural environment, and putting pressure on the Japanese government. This has been the base of something which can be seen as a new form of tourism, which it is possible to call creative (Richards, 2008; 2009), since it can be based on different value creation models, and "eco" (Zeppel, 2006; Mendoza Ramos \& Prideaux, 2014), since it is developed on the preservation of the landscape and the local culture, and it is noteworthy in two ways (Llewellyn, 2016). First, the Ainu's engagement in such a kind of "creative" and "eco-tourism" can be seen as proactive, and an appeal for an understanding the values of the Ainu, such as human-deity relationships, narratives and experience in a modern context. Second, it is viewed as a potential stepping stone to a land claim, which has not been actively demanded by the Ainu to date. As ecotourism is gaining popularity in general, this diversification is a welcome addition.

Although economic, cultural (Codignola, 2016), political and emotional benefits have been achieved to a certain degree, these have not been confirmed. For example, land usage rights have not been affirmed and are not likely to be, at least in the near 
future, due to strong protest by Ainu fishermen. Household income from the fishery villages is high (Hokkaido, 2006) and many of these engage in commercial fishing as part of unions. Although unions were imposed on the Ainu through assimilation policy, these individuals do not want to return to subsistence fishing.

It seems fair to say that the economic, cultural, emotional, and political benefits that indigenous tourism brings are undeniable, but there are drawbacks. Many believe that tourism reproduces prejudice against the Ainu, and makes the Ainu inferior and primitive because performances and displays are seen as stereotypical in the timeless past in tourist centers and in museums (Hiwasaki, 2000), and because "many Ainu willingly lost their culture and traditions in an effort to disassociate themselves from anything Ainu and 'pass' as [Japanese]" (Hiwasaki, 2000, p. 401). To strength this finding, it is useful do add that in 2010 the Japanese government conducted a survey outside Hokkaido, primarily through convenience sampling via mail and phone calls. Although the sample validity is low, some findings are useful (Cotterill, 2011), since some Ainu are hiding their identity even from their spouses and children (Cotterill, 2011), which means that the next generation will not have the choice to identify itself as Ainu.

Furthermore, since people are objectified in tourism, some performers feel humiliated and looked down on even by fellow Ainu (Hiwasaki 2000; Chang et al., 2011). Particularly because of such depictions, 10-20\% of Japanese tourists believe that the Ainu still live in the timeless, old way (Hiwasaki, 2000), thus perpetuating a "negative" image.

Another controversial topic to consider here is the authenticity. Some scholars criticize that authenticity is invented for indigenous/ethnic tourism and thus is not authentic (Hiwasaki, 2000). This criticism should be considered as irrelevant for Ainu tourism because of the Japanese government's ethnocide of the Ainu; tourism was, like it or not, the only venue permitted by the government. Others do not accept modern forms of arts, such as fusion music with non-Ainu instruments, as authentic, while traditional depictions are denied by others as stereotypical (Hiwasaki, 2000). Furthermore, souvenirs are - so far - still targeted for tourist consumption and for this reason some handicrafts are only partially produced by the locals to increase value and reduce cost, and in other cases, souvenirs are mass-produced to meet demand and price points (Chang et al., 2011; Hiwasaki, 2000).

In this scenario, it should be stressed that endemic race discrimination and territorial political issues represent challenges which are shaping the abovementioned situation. For instance, in 2004 Japan applied for Shiretoko, a traditional Ainu town in Hokkaido, to be designated as a UNESCO World Heritage Site (Thornber, 2016), once again excluding any Ainu representation from the research and application process, which is revealing of a complete separation between the aims of the Japanese and those of the Ainu; the Japanese see Ainu tourism as a potential economic asset, which excludes the Ainu from any control over their own culture and social values.

Both Cheung (2003) and Hiwasaki (2000) point, however, that the Ainu people, even those who are heavily involved in the tourist business, are not necessarily proponents of Ainu cultural preservation. One Cheung's research respondent said "the Ainu should adopt modern way since it is not easy or feasible to live in the old ways" (Cheung, 2003, p. 959). This seems somewhat surprising but at the same time it does not; it might be an indication of how deeply discrimination and stigma in 
Japanese society have negatively affected their lives, or how immersed they are in the global economy. Cheung's (2003) sample size, however, is very small: three Ainu individuals. Therefore, it is premature to assume Cheung's (2003) finding can be applied to the Ainu people as a whole. At the same time, the elimination of such prejudice and discrimination against the Ainu is mandatory. Support from international indigenous right movements have been and could still be an effective weapon to fight for improvements in Ainu status. With that support, the Ainu's indigenous voices can be heard, and are no longer a fallen tree in an empty forest as Tsing (2007) asserts.

Within this community, however, there is a great deal of disconnect over what it means to be Ainu, as well, because of the years of suppression by the Japanese governments. As Llewellyn (2016) reports from a field study with the Ainu, for example, one individual claims, with respect to tourism, that,

$\square$ We need Wajin [the Japanese] on board for this. We want them to take part in transmitting Ainu culture to the world, because Ainu themselves lack unity. We'd like to add Wajin blood to the Ainu project and hope that we can strengthen relations between us. But it's also dangerous just making up new varieties of Ainu performance as cultural expressions. We must keep close to the traditional model for everyone's sake. Ainu culture is not a personal possession. (p.72)

What this individual is saying is that there are socio-cultural repercussions to tourism standards that are vague and partially unrelated to actual Ainu culture. So much has been lost in the process of trying to come to terms with the history of suppression that internalized racism and self-prejudice has led to a significant editing of what it means to be Ainu (Llewellyn, 2016; O'Brien, 2016). The benefit of trying to come to terms with this history and creating a new future for the Ainu is, however, important. The process not only allows for the rediscovery of the culture and its traditions, but it also can create jobs and even new professions in the region so that fewer people feel as if they have to assimilate with the Japanese (Chang et al, 2011). There is a value in building up what has been lost over the long term and rediscovering what it means to be a part of this indigenous group.

\section{Ecotourism and Local Stakeholders: Thinking About Some Emerging Issues}

The management of such touristic destinations, motivated more by generating profit than developing the local communities, is characterised by a lack of what we can call low-power stakeholder engagement (Greenwood, 2007; Civera et al., 2018) in tourism (Greenwood, 1989). The result is that many local goods and services have been mass-produced and simplified in order to better suit tourists' interests and predilections (Chang et al., 2011), in a sort of culture commoditisation (Hiwasaki, 2000). In the light of this, local stakeholders no longer have a clear interest in engaging in their own crafts and arts but literally prefer to keep those things to themselves rather than share them with the consumers (Llewellyn, 2016). 
In order to understand the reality that the Ainu are facing, it is time to conduct a nationwide survey. This is echoed by the UN; according to the Ainu Association of Hokkaido (2015), "[a] nationwide actual condition survey was requested by the U.N. Committee on the Elimination of Racial Discrimination, but has not been conducted" (p. 15). However questionable, the 2010 attempt discussed in the previous section has been useful both for the case itself and, from a purely theoretical point of view, for the application of the lens of stakeholder theory (Freeman, 1984; Freeman et al., 2010) and its core: relationships. Once the size of the Ainu population is known, it could increase if segregation decreases and if the Ainu do not feel ashamed and afraid of being identified as such; or it could decrease if their situation does not change.

The gathered secondary data in the previous section confirm the fact that power imbalance has a strong link to a lack of knowledge and relationships among the players in a certain territory (Sautter \& Leisen, 1999; Greenwood, 2007; Freeman et al., 2010). Furthermore, these lacks aggravate the situation, in terms of distances between the territory players, inequalities and, as a consequence, difficulties using the Ainu's culture, heritage and authenticity (Leonidou, 2015; Spielmann et al., 2018) for developing the Hokkaido tourism.

The future of tourism for the Ainu may lie in an ecological and environmental approach, with the aim of creating local jobs (Richards, 2009) for an enhanced and involved community (Greenwood \& Van Buren III, 2010). A strategy for ecotourism, which sits outside the control of the Japanese, is a proactive stance (whereof the importance was already discussed in 1999 by Sautter \& Leisen) that may help to redefine the identity of this community and what is valuable to it (O'Brien, 2016) in a creative way, by developing new business models (Richards, 2009), which need to be first of all resident-inclusive (Sautter \& Leisen, 1999; Freeman et al., 2010). As Llewellyn (2016) explains, this could help the Ainu community begin to unpack what they can retain from their traditional knowledge, and what they can envision for their ethnic group in the future.

In order for things to change, the Ainu must have complete control over their futures within Japanese borders, and they must be able to negotiate independently with those outside Japan who want to support them. The Ainu need to be able to learn from the challenges that other indigenous groups have faced in order to reclaim what is theirs and discover a new way of engaging in tourism on their own terms, as advocated by the concept of creative tourism (Richards, 2008; Richards, 2009). In doing so, they may also be able to reclaim their community power (Greenwood \& Van Buren III, 2010) and create a new way of seeing themselves outside the structural discrimination and oppression that they have faced in the past (Ono \& Ono, 2015). It is hoped that the Ainu can achieve this with the support of the world around them, under the logic of joint interests (Freeman et al., 2010) and joint value creation (Bridoux \& Stoelhorst, 2013), since theirs is a territory which represents a UNESCO site, a land of global interest.

However, in order for this idea of international cultural heritage to work (Danesi, 2017), it must above all be equitable, and the Ainu must directly participate by finally engaging in what they do, confirming the importance of local stakeholder inclusion (Greenwood, 2007; Boiral \& Heras-Saizarbitoria, 2017; Fassin et al., 2017). Countries that have the resources to preserve and promote their own cultural heritage should not be the only ones who are able to meet the criteria of a UNESCO designation. Affluent countries such as Japan could make financial contributions for 
a better preservation of the Ainu, but this would have to take place without interference. The equal promotion of all indigenous sites in Japan needs to be a priority as well. Although there is a tourism industry value for developing countries to have a place designated as a cultural heritage site, at the same time those same regions must ensure that the financial incentive is not the only one. A site will not serve as a marker of global cultural heritage if it is destroyed by a rapid increase in tourist traffic.

The issues of appropriation, identity and politics surrounding cultural heritage are key to understanding who owns heritage (Danesi, 2017) in Japan. The idea of a global cultural heritage linked to the Ainu culture in some ways suggests that it may be very difficult to define who owns what. The ideal would be that all global citizens have a stake in global cultural remains, as well as in how we keep cultures alive. However, that ideal may very well be unrealistic. It is instinctive to agree that local stakeholders can and should participate in issues related to their own culture (Greenwood, 2007; Greenwood \& Van Buren III, 2010; Harrison \& Wicks, 2010; Jones \& Felps, 2013; Dawkins, 2015; Fassin et al., 2017; Boiral \& Heras-Saizarbitoria 2017; Civera et al., 2018).

True and effective participation in cultural heritage management requires that conflicts should tend towards the conservative rather than the collaborative (Fassin et al., 2017). When it comes to physical bodies, cultural considerations are often more emotional. Finally, cultural imperialism must be examined from both sides of the participation debate because of the fact that more indigenous groups are assuming the power to control their cultural aims and tourism in their local communities.

Furthermore, Ainu cultural history is valuable in that it provides the opportunity to learn from the Japanese's mistakes and build on their successes, and in that sense, it needs to be shared by all stakeholders. Without a historical assessment of the Ainu and of the Japanese monoculture, we would not be able to develop the means through which we can evaluate how this issue has evolved over time. There are valuable contributions not only from historical documents and artefacts related to Ainu culture but also from oral accounts of what has occurred (Hennessey, 2017). Of all the historical pieces of evidence available to us, however, it may be argued that the most valuable and compelling are stories told by people about their personal experiences. From an academic point of view, traditional histories as narrated by the Ainu themselves can offer us the greatest insight into what life was like in the past. Material artefacts are interesting and illustrative, but unless we truly understand how they were used and in what context, they have very little value. However, there is an inherent challenge in sharing history because of the rise in the claims of ownership of cultures and cultural history among international bodies, including governments, organisations and special interest groups.

\section{Conclusions and Limitations}

To conclude, the only way to exploit tourism in that Japanese territory is to really work on relationships, rather than on transactions (Freeman et al., 2010), and on Ainu social inclusion, since power imbalances have a definitive impact on the social structure of the role of indigenous groups over the long term. This means that from a tourism perspective, indigenous can act as agents but may also be unable to do so 
within contexts that limit them to a certain way of being. For the Ainu people, this means that racialisation may limit the application of agency (Ono \& Ono, 2015; Siddle, 2012).

This theoretical paper has limitations, since it is all based on secondary data which were not thought in order to fully explain all the roots of the already cited and investigated concepts of power imbalances and the consequences of these low power stakeholders' inclusion, even if the approach we utilized could help us to find sufficient implication and good food for thought for further research. For this reason, the present paper represents a first attempt at joint interest and value creation, rather than a complete case analysis. It raises, indeed, questions about the importance of a real involvement of the Ainu population in its cultural and economic issues, about how to motivate people by promoting the concept of a common territorial value creation, authenticity, benefits and positive values, and about how to create a new (= creative) model of tourism management which addresses the above-mentioned issues.

\section{Bibliography}

Adger, W. N., Brown, I., \& Surminski, S. (2018). Advances in Risk Assessment for Climate Change Adaptation Policy. Philosophical Transactions of The Royal Society A. Mathematical, Physical and Engineering Sciences, 376(2121): 20180106.

http://dx.doi.org/10.1098/rsta.2018.0106

Ainu Association of Hokkaido. (2015). Actual living conditions of Hokkaido Ainu. Available at: http://www.ainu-assn.or.jp/english/eabout03.html

Anaya, S. (2006). Indigenous Peoples in International Law. Oxford: OUP.

Boiral, O., \& Heras-Saizarbitoria, I. (2017). Managing Biodiversity Through Stakeholder Involvement: Why, Who, and for What Initiatives? Journal of Business Ethics, 140(3), 403-421. http://dx.doi.org/10.1007/s10551-015-2668-3

Bridoux, F., \& Stoelhorst, J. W. (2014). Microfoundations for Stakeholder Theory: Managing Stakeholders with Heterogeneous Motives. Strategic Management Journal, 35(1), 107-125.

http://dx.doi.org/10.1002/smj.2089

Brondoni, S. M. (2014). Ouverture de 'Global Networks and Sustainable Development - 1', Symphonya. Emerging Issues in Management (symphonya.unimib.it), (1), 1-9.

http://dx.doi.org/10.4468/2014.1.01ouverture

Brondoni, S. M., Bosetti, L. \& Civera, C. (2019). Ouverture de 'CSR and Multi-Stakeholder Management', Symphonya. Emerging Issues in Management (symphonya.unicusano.it), (1), 1-15. http://dx.doi.org/10.4468/2019.1.01ouverture

Candelo, E., Casalegno, C., Civera, C., \& Mosca, F. (2018). Turning Farmers into Business Partners through Value Co-Creation Projects. Insights from the Coffee Supply Chain. Sustainability, 10(4), 1018.

http://dx.doi.org/10.3390/su10041018

Centeno, M. (2015). The Shapes of Otherness: the Representation of the Ainu People in Brodsky's Travelogues 1918-1919. Kokoro, Revista para la Difusión de la Cultura Japonesa, (17), 14-22. Available at:

http://eprints.soas.ac.uk/id/eprint/24129

Chang, J., Su, W.Y. \& Chang, C.C. (2011). The Creative Destruction of Ainu Community in Hokkaido, Japan. Asia Pacific Journal of Tourism Research, 16(5), 505-516.

http://dx.doi.org/10.1080/10941665.2011.597576 
Cheung, S. C. (2003). Ainu culture in transition. Futures, 35(9), 951-959.

http://dx.doi.org/10.1016/S0016-3287(03)00051-X

Civera, C., De Colle, S., \& Casalegno, C. (2019). Stakeholder Engagement Through Empowerment: The Case of Coffee Farmers, Business Ethics: A European Review, 28(2), 156-174.

http://dx.doi.org/10.1111/beer.12208

Clammer, J. (2018). The fabric of indigeneity: Ainu identity, Gender, and Settler Colonialism in Japan. Ethnic and Racial Studies, 41(3), 577-578.

http://dx.doi.org/10.1080/01419870.2017.1332382

Codignola, F. (2017). Culture and Creativity Management: Milan as a Global Capital for Value Creation. Symphonya. Emerging Issues in Management (symphonya.unimib.it), (2), 108-124.

http://dx.doi.org/10.4468/2016.2.10codignola

Cotterill, S. (2011). Documenting Urban Indigeneity: Tokyo Ainu and the 2011 Survey on the Living Conditions of Ainu Outside Hokkaido, The Asia-Pacific Journal 9(45), 1-14.

https://apjif.org/2011/9/45/Simon-Cotterill/3642/article.html

Danesi, S. (2017). The Role of Culture Heritage in Commercial Development and Tourism. Symphonya. Emerging Issues in Management (symphonya.unimib.it), Special Issue 1, 48-58.

http://dx.doi.org/10.4468/2017.3.05danesi

Dawkins, C. E. (2014). The Principle of Good Faith: Toward Substantive Stakeholder Engagement. Journal of Business Ethics, 121(2), 283-295.

http://dx.doi.org/10.1007/s10551-013-1697-z

Derry, R. (2012). Reclaiming Marginalized Stakeholders. Journal of Business Ethics, 111, 253-264. http://dx.doi.org/10.1007/s10551-012-1205-x

Durkheim, É. (1893/1984). The Division of Labour in Society. London: Free Press.

Fassin, Y., De Colle, S., \& Freeman, R. E. (2017). Intra-stakeholder alliances in plant-closing decisions: A stakeholder theory approach. Business Ethics: A European Review, 26(2), 97-111.

http://dx.doi.org/10.1111/beer.12136

Freeman, R. E. (1984). Stakeholder management: framework and philosophy. Pitman, Mansfield, MA.

Freeman, R. E., Wicks, A., Harrison, J., Parmar, B., \& de Colle, S. (2010). Stakeholder Theory: The State of the Art, Cambridge University Press, Cambridge, UK.

Freeman, E. R., Civera, C., Cortese, D., \& Fiandrino, S. (2018). Strategising Stakeholder Empowerment for Effective Co-Management within Fishery-based Commons. British Food Journal, 120(11), 2631-2644.

http://dx.doi.org/10.1108/BFJ-01-2018-0041

Greenwood, D. J. (1989). Culture by the Pound: An Anthropological Perspective on Tourism as Cultural Commoditization, in Smith V. L. (ed.), Hosts and Guests: The Anthropology of Tourism., (Ed. 2), 171-185. University of Pennsylvania Press: Philadelphia.

Greenwood, M. (2007). Stakeholder Engagement: Beyond the Myth of Corporate Responsibility, Journal of Business Ethics, 74 (4), 315-327.

http://dx.doi.org/10.1007/s10551-007-9509-y

Greenwood, M., \& Van Buren III, H. J. (2010). Trust and Stakeholder Theory: Trustworthiness in the Organisation-Stakeholder Relationship", Journal of Business Ethics, 95(3), 425-438.

http://dx.doi.org/10.1007/s10551-010-0414-4

Harrison, J. S., \& Wicks, A. C. (2013), Stakeholder Theory, Value, and Firm Performance, Business Ethics Quarterly, 23(101), 97-124.

http://dx.doi.org/10.5840/beq20132314

Hennessey, J. (2017). American Advisors, Ainu 'Artefacts' and Japanese Settler Colonialism in Hokkaidō, 1868-1885. Proceeding of the Conference Everyday Empires: Trans-Imperial Circulations in a Multidisciplinary Perspective, May 25-26, 2017, University of Birmingham, UK. 
Hiwasaki, L. (2000). Ethnic Tourism in Hokkaido and the Shaping of Ainu Identity. Pacific Affairs, 393-412.

http://dx.doi.org/10.2307/2672026

Hokkaido Ainu Policy Promotion Office. (2017). Ainu living conditions. Retrieved from: http://www.pref.hokkaido.lg.jp/ks/ass/jittai.htm

Hohmann, S. (2008). The Ainu's Modern Struggle. World Watch, 21, 20-23. Available at: http://www.skyehohmann.com/The\%20Ainu's\%20Modern\%20Struggle.pdf

Honey, M., \& Thullen, S. (Eds.). (2003). Rights and Responsibilities: a Compilation of Codes of Conduct for Tourism and Indigenous \& Local Communities. Center on Ecotourism and Sustainable Development/The International Ecotourism Society. Available at:

https://trove.nla.gov.au/version/33446767

Jamali, D., \& Neville, B. (2011). Convergence versus Divergence of CSR in Developing Countries: An Embedded Multi-layered Institutional Lens. Journal of Business Ethics, 102(4), 599-621.

http://dx.doi.org/10.1007/s10551-011-0830-0

Leonidou, L. C., Coudounaris, D. N., Kvasova, O., \& Christodoulides, P. (2015). Drivers and Outcomes of Green Tourist Attitudes and Behavior: Sociodemographic Moderating Effects. Psychology and Marketing, 32(6), 635-650.

http://dx.doi.org/10.1002/mar.20806

Llewellyn, A.E. (2016). "Clamoring Blood”: The Materiality of Belonging in Modern Ainu Identity. Critical Asian Studies, 48(1), 50-76.

http://dx.doi.org/10.1080/14672715.2015.1131400

McNamara, N., Stevenson, C., \& Muldoon, O. T. (2013). Community Identity as Resource and Context: A Mixed Method Investigation of Coping and Collective Action in a Disadvantaged Community. European Journal of Social Psychology, 43(5), 393-403.

http://dx.doi.org/10.1002/ejsp.1953

Ramos, A. M., \& Prideaux, B. (2014). Indigenous Ecotourism in the Mayan Rainforest of Palenque: Empowerment Issues in Sustainable Development. Journal of Sustainable Tourism, 22(3), 461-479. http://dx.doi.org/10.1080/09669582.2013.828730

Mizuno, T. (1987). Ainu, the Invisible Minority. Japan Quarterly, 34(2), 143-148. Available at: https://search.proquest.com/docview/1304275368?accountid=14368

Morley, D. (2006). Globalisation and Cultural Imperialism Reconsidered, in Curran, J., \& Morley, D. (eds), Media and Cultural Theory, Routledge: New York.

Nakamura, N. (2007). The Representation of Ainu Culture in the Japanese Museum System. The Canadian Journal of Native Studies, 27(2), 331. Available at:

http://www3.brandonu.ca/cjns/27.2/04Nakamura.pdf

O’Brien, P. (2016). A Tale of Two Worlds: The Ainu and the Wajin. Agora, 51(3), 63. Available at: https://search.informit.com.au/documentSummary;dn=326876659008199;res=IELHSS

Ono, H., \& Ono, H. (2015). Race and Ethnic Relations in Contemporary Japan, in The International Handbook of the Demography of Race and Ethnicity (pp. 219-237). Springer: Dordrecht.

Phillip, S., Hunter, C., \& Blackstock, K. (2010). A typology for Defining Agritourism. Tourism Management, 31(6), 754-758.

http://dx.doi.org/10.1016/j.tourman.2009.08.001

Potts, P. (2003). Modernising education in Britain and China: Comparative perspectives on excellence and social inclusion. Routledge.

Powell, W. W., \& Snellman, K. (2004). The Knowledge Economy. Annual Review of Sociology, 30, 199-220.

http://dx.doi.org/10.1146/annurev.soc.29.010202.100037

Ramos, A. R. (1998). Indigenism: Ethnic politics in Brazil. Madison, London: University of Wisconsin Press. 
Richards, G. (2008). Creative Tourism and Local Development. In Santa Fe International Conference on Creative Tourism, September

Richards, G. (2009) Creative tourism and local development. In: Wurzburger, R., Pattakos, A. \& Pratt, S. (eds) Creative Tourism: A global conversation. Santa Fe: Sunstone Press, pp. 78-90.

Roadnight, A. (2002). Sleeping with the Enemy: Britain, Japanese Troops and the Netherlands East Indies, 1945-1946. History, 87(286), 245-268.

http://dx.doi.org/10.1111/1468-229X.00223

Saito, S. (2015). Ainu: “Homogenous” Japan's Indigenous People, in Children's Images of Identity (pp. 131-147). Springer, Rotterdam.

Salvioni, D. M., \& Astori, R. (2013). Sustainable Development and Global Responsibility in Corporate Governance. Symphonya Emerging Issues in Management (symphonya.unimib.it), (1), 28-52.

http://dx.doi.org/10.4468/2013.1.03salvioni.astori

Salvioni, D. M, \& Bosetti, L. (2014). Sustainable Development and Corporate Communication in Global Markets, Symphonya. Emerging Issues in Management (symphonya.unimib.it), (1), 32-51.

http://dx.doi.org/10.4468/2014.1.03salvioni.bosetti

Sautter, E. T., \& Leisen, B. (1999). Managing Stakeholders; a Tourism Planning Model. Annals of Tourism Research, 26(2), 312-328.

http://dx.doi.org/10.1016/S0160-7383(98)00097-8

Siddle, R. (2003), The Limits to Citizenship in Japan: Multiculturalism, Indigenous Rights and the Ainu, Citizenship Studies, 7(4), 447-462.

http://dx.doi.org/10.1080/1362102032000134976

Siddle, R. M. (2012). Race, Resistance and the Ainu of Japan. Routledge: Sheffield.

Snyder, H. (2019). Literature Review as a Research Methodology: An Overview and Guidelines. Journal of Business Research, 104, 333-339.

http://dx.doi.org/10.1016/j.jbusres.2019.07.039

Statistics Bureau of Japan. (2011). Population Census. Retrieved from:

http://www.stat.go.jp/english/index.htm

Thornber, K. (2016). Humanistic Environmental Studies and Global Indigeneities. Humanities, 5(3), $52-58$.

http://dx.doi.org/10.3390/h5030052

Tsing, A. (2007). Indigenous voice. In M. Cadena \& O. Starn. (Eds.), Indigenous Experience Today, 33-67. Oxford \& New York, NY: Berg.

United Nations. (2007). United Nations Declaration on the Rights of Indigenous Peoples. Available at: http://www.un.org/esa/socdev/unpfii/en/declaration.html

Venkataraman, S. (2002). Stakeholder Value Equilibration and the Entrepreneurial Process. The Ruffin Series of the Society for Business Ethics, 3, 45-57.

http://dx.doi.org/10.5840/ruffinx2002313

World Tourism Organization. (2018). Why tourism? Available at: http://www2.unwto.org/en/content/why-tourism

Yamasaki, K., \& Miller, M. (2017). Ainu Aesthetics and Philosophy of Art. In New Essays in Japanese Aesthetics, 139. Rowman \& Littlefield.

Zeppel, H. (2006). Indigenous ecotourism: Sustainable development and management (Vol. 3). Cabi. 